\title{
Comparative Study of Serum Magnesium and Lipid Profile in Normal Weight, Over-Weight and Obese Young Adult Males
}

${ }^{1}$ Sabiha Iqbal, ${ }^{1}$ Humera Wyne, ${ }^{2}$ Syed Imran Ali Shah

${ }^{1}$ Department of Physiology, Central Park Medical College, Lahore

${ }^{2}$ Department of Biochemistry, Central Park Medical College, Lahore

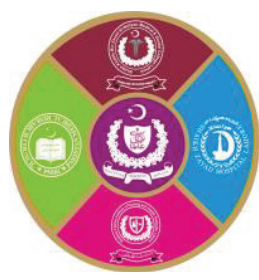

\begin{abstract}
Introduction: The worldwide pandemic of obesity is a disorder characterized by excessive buildup of body fat. Obese individuals typically consume unhealthy high caloric food that is usually low in mineral and vitamins. Abnormalities in serum magnesium $(\mathrm{Mg})$ levels have been seen in obesity. $\mathrm{Mg}$ plays a key role in regulating glucose and lipid metabolism. Aims \& Objectives: To compare serum Mg, triglyceride(TG), low density lipoproteins (LDL), very low density lipoproteins (VLDL) and high density lipoproteins (HDL) levels in overweight and obese males with age-matched normal weight males and to correlate serum $\mathrm{Mg}$ levels with lipid profile. Place and duration of study: The study was conducted in the Department of Physiology, Central Park Medical College in collaboration with Central Park Teaching Hospital within a time period from $5^{\text {th }}$ Jan 2018 to $15^{\text {th }}$ Sep 2018. Material \& Methods: In this cross-sectional comparative study, 40 overweight and obese male subjects were included having a body mass index (BMI) $>25 \mathrm{Kg} / \mathrm{m}^{2}$. Another age-matched 40 non-obese males with a BMI $<25 \mathrm{Kg} / \mathrm{m}^{2}$ were included as controls. Serum $\mathrm{Mg}$ levels were measured by atomic absorption spectrophotometry. Serum TG, LDL, VLDL and HDL levels were measured by direct quantitative method using spectrophotometry. Results: Lower serum Mg levels and higher serum VLDL and TG levels were present in overweight and obese males as compared to controls. No significant difference was found in serum LDL and HDL levels. Significant inverse proportionality was present between serum $\mathrm{Mg}$ and VLDL \& TG levels in the group comprising of overweight and obese men. Conclusion: Serum Mg was negatively correlated with serum VLDL and TG highlighting the role of serum Mg in regulation of lipid metabolism. Deficiency of serum magnesium could contribute to dyslipidemia found in obesity.
\end{abstract}

Key words: Obesity, Lipid profile, Magnesium

\section{INTRODUCTION}

$\mathrm{O}$ besity is an ailment caused by increased body fat deposition having adverse health outcomes. It is one of the most serious global health problems ${ }^{1}$ and is a risk factor for many non-communicable illnesses. Obesity is prevalent worldwide across all age groups. ${ }^{2}$ It is estimated to be the second leading cause of mortality and morbidity in the world. ${ }^{3}$ Body mass index (BMI) is considered as gold standard for assessment of obesity. According to World Health Organization (WHO) criteria for BMI, normal range of BMI is $18.5-24.9 \mathrm{Kg} / \mathrm{m}^{2}$, overweight is $\geq 25 \mathrm{Kg} / \mathrm{m}^{2}$ and obesity is $\geq 30 \mathrm{Kg} / \mathrm{m}^{2}$. ${ }^{4}$ According to Pakistan National Representative Survey, $25 \%$ of Pakistani population is overweight and $10.3 \%$ is obese. ${ }^{5}$ About $20 \%$ of body fat is stored as visceral fat and is linked with metabolic abnormalities (mainly type 2 diabetes), hypertension and coronary artery disease. ${ }^{6}$ Increased adiposity leads to invasion by macrophages with release of various cytokines that causes low grade inflammation found in obesity. ${ }^{7}$

Obesity is linked with magnesium $(\mathrm{Mg})$ deficiency. ${ }^{8}$ Despite the various dietary sources of $\mathrm{Mg}$ such as green leafy vegetables, nuts and legumes, $\mathrm{Mg}$ intake is inadequate. ${ }^{9}$ Deficiency of $\mathrm{Mg}$ in rats has been shown to result in an inflammatory syndrome in which there is activation of leukocyte and macrophage, production of inflammatory cytokines and acute-phase proteins, and extensive free radical production. An increase in $\mathrm{Mg}$ concentration extracellularly causes the inflammatory effects to be decreased, while a reduction in extracellular $\mathrm{Mg}$ levels resulted in the inflammatory cell activation. ${ }^{10}$ The human body cells require $\mathrm{Mg}$ as a cofactor in numerous enzymatic reactions like ATP for kinases, 
regulate the ion channels and it is also important factor in both humoral and cellular immunity. ${ }^{11}$ Hypomagnesemia causes impairment of tyrosine kinase function at insulin receptor which results in insulin resistance. The lipid changes in diabetes are thought to be a consequence of increase fatty acid release from insulin resistant fat cells. In due course insulin resistance along with decreased magnesium levels result in a vicious cycle of worsening the condition. ${ }^{12} \mathrm{Mg}$ deficiency also has a role in the release of insulin so its deficiency can lead to perturbation of glucose and lipid metabolism. . $^{13,14}$ The beneficial effects of magnesium supplementation on lipid profile have also been witnessed in some studies on diabetic patients. ${ }^{15}$

Serum magnesium has not been studied in the local population particularly in the context of impact of body weight and lipid profile in young adults. The present work studied the comparison of serum $\mathrm{Mg}$, triglyceride (TG), low density lipoproteins (LDL), very low density lipoproteins (VLDL) and high density lipoproteins (HDL) levels in overweight and obese males with age-matched normal weight males and investigated the correlation of serum $\mathrm{Mg}$ levels with lipid profile.

\section{MATERIAL AND METHODS}

A cross-sectional, comparative study design was employed. The study was conducted at department of Physiology, Central Park Medical College (CPMC), Lahore. Group 2 consisted of 40 overweight and obese males between the ages 18-30 years based on BMI cut-off of $25 \mathrm{~kg} / \mathrm{m}^{2}$ and above. An equal number of age matched healthy subjects were recruited as controls (Group 1) having BMI less than $25 \mathrm{~kg} / \mathrm{m}^{2}$. Only those subjects were included who had no history of diabetes, hypertension, coronary artery disease and who were not taking medication for any chronic illness. After approval from CPMC Ethical Review Board, all the participants were informed about the study and consent was taken from willing subjects. Sociodemographic data and anthropometric measures for BMI calculations were recorded on the study proforma. $4 \mathrm{ml}$ of venous blood sample was drawn using aseptic technique from each participant after an overnight fast. The blood sample was added to gel activating vacutainers for serum extraction. Serum Mg levels were measured by atomic absorption spectrophotometry. Serum TG, LDL, VLDL and HDL levels were measured by direct quantitative method using spectrophotometry.

\section{Statistical analysis:}

The data was analyzed using SPSS software. Shapiro-Wilk test was applied to check the normality of data which showed that the data were non-normally distributed. Non-parametric Mann Whitney $\mathrm{U}$ test was applied to compare group data and a $\mathrm{p}$-value $<0.05$ was considered as statistically significant value.

\section{RESULTS}

Median (IQR) serum Mg levels of group II was significantly lower than group I $(p=0.020)$. The difference between group I median (IQR) fasting serum LDL and HDL and Group II LDL \&HDL was not statistically significant $(\mathrm{p}=0.143)(\mathrm{p}=0.421)$. Median (IQR) fasting serum triglycerides in Group I was significantly lower than group II $(p=0.020)$. Median (IQR) fasting serum VLDL of was found to be statistically lower in group I than in group II $(p=$ 0.023).

Significant negative correlation was present between serum Mg and VLDL \& TG levels in group II. The correlation of serum magnesium with other study variables in individual group I and group II was not found to be significant as mentioned in Table-2.

\begin{tabular}{|c|c|c|c|c|c|}
\hline \multirow{3}{*}{ Parameters } & \multirow{3}{*}{ Group I } & \multirow{3}{*}{ Group II } & \multirow{2}{*}{\multicolumn{2}{|c|}{\begin{tabular}{|c|} 
Mean rank \\
GROUP
\end{tabular}}} & \multirow{3}{*}{$\begin{array}{c}P \\
\text { Value }\end{array}$} \\
\hline & & & & & \\
\hline & & & T & II & \\
\hline $\begin{array}{l}\text { - Serum Magnesium } \\
(\mathrm{mg} / \mathrm{dl}) \\
\text { Median (IQR) }\end{array}$ & $\begin{array}{c}1.265 \\
(1.042-1.445)\end{array}$ & $\begin{array}{c}1.055 \\
(0.512-1.36)\end{array}$ & 46.56 & 34.44 & $0.020 *$ \\
\hline $\begin{array}{l}\text { - Fasting serum } \\
\text { LDL(mg/dl) } \\
\text { Median (IQR) }\end{array}$ & $\begin{array}{c}82 \\
(69.25-96.25)\end{array}$ & $\begin{array}{c}93 \\
(67.7-116)\end{array}$ & 36.7 & 44.3 & 0.143 \\
\hline $\begin{array}{l}\text { Fasting serum } \\
\text { HDL(mg/dl) } \\
\text { Median (IQR) }\end{array}$ & $\begin{array}{c}40 \\
(36-47)\end{array}$ & $\begin{array}{c}38.5 \\
(33.2-45.7)\end{array}$ & 42.59 & 38.41 & 0.421 \\
\hline $\begin{array}{l}\text { - Fasting serum TG } \\
(\mathrm{mg} / \mathrm{dl}) \\
\text { Median (IQR) }\end{array}$ & $\begin{array}{c}92.5 \\
(63-130) \\
\end{array}$ & $\begin{array}{c}116.5 \\
(83.7-206.2) \\
\end{array}$ & 34.45 & 46.55 & $0.020 *$ \\
\hline $\begin{array}{l}\text { - Fasting serum } \\
\text { VLDL(mg/dl) } \\
\text { Median (IQR) }\end{array}$ & $\begin{array}{c}18.50 \\
(12.25-26.0) \\
\end{array}$ & $\begin{array}{c}23 \\
(16.5-41.25) \\
\end{array}$ & 34.66 & 46.4 & $0.023 *$ \\
\hline
\end{tabular}

- Using Mann Whitney U Test

p-value $<0.05 *$ is considered significant.

Table-1: Comparison of serum Magnesium and Lipid Profile between Group I and Group II 


\begin{tabular}{|c|c|c|c|}
\hline Groups & Parameter & $\begin{array}{c}\text { Corelation } \\
\text { coefficient (r) }\end{array}$ & $\boldsymbol{p}$ value \\
\hline \multirow{3}{*}{$\begin{array}{c}\text { Group I } \\
\mathrm{n}=40\end{array}$} & TG & 0.760 & 0.62 \\
\cline { 2 - 4 } & VLDL & 0.740 & 0.651 \\
\cline { 2 - 4 } & HDL & 0.160 & 0.325 \\
\hline \multirow{3}{*}{$\begin{array}{c}\text { GDL } \\
\text { n=40 II }\end{array}$} & TG & 0.143 & 0.380 \\
\cline { 2 - 4 } & VLDL & -0.475 & $0.002^{*}$ \\
\cline { 2 - 4 } & HDL & 0.478 & $0.002^{*}$ \\
\cline { 2 - 4 } & LDL & 0.147 & 0.922 \\
\hline
\end{tabular}

$\mathrm{p}$-value $<0.05 *$ is considered significant.

Table-2: Spearman corelation of magnesium with various parameters of study

\section{DISCUSSION}

The current study showed serum $\mathrm{Mg}$ to be significantly lower in obese and overweight individuals as compared to those with weight in the normal range of BMI $(p=0.020)$. These findings are consistent with other studies conducted previously that have shown a link between obesity and the micronutrient deficiencies. ${ }^{16,17}$ The results are in concordance with the work of Nielsen et al., which showed low serum Mg levels in obese individuals because of its lower dietary intake. ${ }^{18,19}$ In the other perspective intake of whole grain, vegetables and nuts which are rich sources of magnesium are found to be inversely related to the body weight. ${ }^{20}$

Besides $\mathrm{Mg}$ deficiency, the present study has also revealed dyslipidemia in overweight and obese individuals with raised TG and VLDL but near normal LDL and HDL levels which is in line with a prior study by Corica et al. ${ }^{21}$ The effects of $\mathrm{Mg}$ on lipids are independent of its effects on insulin secretion. $\mathrm{Mg}$ serves as a cofactor for many enzymes involved in lipid metabolism. Magnesium decreases TG and LDL levels and is found to increase the HDL cholesterol levels by inhibiting various enzymes, e.g, lecithin cholesterol acyl transferase (LCAT) ${ }^{22}$ and lipoprotein lipase. ${ }^{23}$ The lipoprotein lipase is involved in conversion of triglycerides to HDL cholesterol. The valuable effects of magnesium over the lipid metabolism are seen in various animals ${ }^{24}$ and some epidemiological ${ }^{25}$ and other studies. ${ }^{26,27}$ Our study is also supported by other studies in diabetics in which low magnesium levels were associated with a significant rise in triglycerides and LDL cholesterol and a fall in HDL cholesterol. ${ }^{28}$

$\mathrm{Mg}$ depletion has been found to be associated with insulin resistance and atherogenic potential. Insulin resistance has principal role in the development of dyslipidemia because insulin resistant adipose tissue releases more amounts of free fatty acids (FFA). This augmented FFA flux into the liver despite of sufficient glycogen reserves promotes enhanced triglyceride production. The increased TGs results in increased secretion of VLDL cholesterol and apolipoprotein B (Apo-B). Hepatic VLDL cholesterol synthesis is markedly enhanced because of inability of insulin to prevent the release of FFA, showing its correlation with hepatic fat accumulation. ${ }^{29}$

High VLDL can reduce HDL concentrations by enhancing the exchange from HDL cholesterol to VLDL variety through cholesteryl ester transfer protein. Furthermore, the decreased removal of lipids as well as lipoproteins also results in dyslipidemia. Additionally, another protein which mediate the transferal of triglycerides from VLDL to LDL enhances the formation of LDL cholesterol. In rats a low magnesium diet produced increase in triglycerides and plasma glucose levels. ${ }^{30}$ Dietary $\mathrm{Mg}$ restriction in maternal rats is found to be associated with insulin resistance in pups. ${ }^{31}$

A significant negative correlation was present between serum Mg and VLDL \& TG levels in group II. The correlation of serum $\mathrm{Mg}$ with serum LDL and HDL in both groups and with TG \& VLDL in control group was found to be non-significant which may be explained by relatively small sample size, younger age of the participants and cross-sectional design of the study.

\section{CONCLUSION}

The present study supports the role of reduced serum magnesium levels in dyslipidemia found in obese males. Lower levels of serum magnesium alter lipid profile by increasing the levels of serum TGs. This micronutrient deficiency may possibly contribute to the development of metabolic syndrome. Further work employing $\mathrm{Mg}$ supplementation may provide better insights into the potential biochemical and clinical benefits of serum $\mathrm{Mg}$.

\section{REFERENCES}

1. DiBaise JK, Foxx-Orenstein AE. Role of the gastroenterologist in managing obesity. Expert Rev Gastroenterol Hepatol. 2013; 7(5):439-51.

2. Ofei F. Obesity-a preventable disease. Ghana Med J. 2005; 39(3): 98-101.

3. Data GA. Australia's health 2016. Diabetes. 2011; 12(5.0):2-3.

4. Kanazawa M, Yoshiike N, Osaka T, Numba Y, Zimmet $\mathrm{P}$, Inoue S. Criteria and classification of obesity in Japan and Asia-Oceania. Asia Pac J ClinNutr. 2002; 11:S732-7. 
5. Humayun A, Shah AS, Alam S, Hussein H. Relationship of body mass index and dyslipidemia in different age groups of male and female population of Peshawar. J Ayub Med Coll Abbottabad. 2009; 21(2):141-4.

6. Deepa R, Sandeep S, Mohan V. Abdominal obesity, visceral fat and Type 2 diabetes "Asian Indian Phenotype". Type 2 Diabetes in South Asians: Epidemioliogy, risk factors prevention. 2006:138-152.

7. Choi SH, Hong ES, Lim S. Clinical implications of adipocytokines and newly emerging metabolic factors with relation to insulin resistance and cardiovascular health. Front. Endocrinol. 2013; 4:97.

8. Huerta MG, Roemmich JN, Kington ML, Bovbjerg VE, Weltman AL, Holmes VF, Patrie JT, Rogol AD, Nadler JL. Magnesium deficiency is associated with insulin resistance in obese children. Diabetes care. 2005; 28(5): 1175-81.

9. Guerrera MP, Volpe SL, Mao JJ. Therapeutic uses of magnesium. Am Fam Physician. 2009; 80(2).

10. Rayssiguier Y, Libako P, Nowacki W, Rock E. Magnesium deficiency and metabolic syndrome: stress and inflammation may reflect calcium activation. Magnes Res. 2010; 23(2): 73-80.

11. Phuong-Chi T. Pham, Phuong-Mai T. Pham, Son V. Pham, Jeffery M. Miller and PhuongThu. Pham. Hypomagnesemia in Patients with Type 2 Diabetes. Clinical journal of the American Society of Nephrology 2007;2:366-73

12. Mishra S, Padmanaban P, Deepti GN, Sarkar G, Sumathi S, Toora BD. Serum magnesium and dyslipidemia in type-2 diabetes mellitus. Biomed Res. 2012; 23(2):295-300.

13. Nasri H, Baradaran HR. Lipids in association with serum magnesium in diabetes mellitus patients. Bratisl Med J. 2008; 109(7):302-6.

14. Nasri H. Lipids in association with serum magnesium in diabetes mellitus patients. Acta Angiologica. 2006; 12(4):149-54.

15. Lal J, Vasudev K, Kela AK, Jain SK .Effect of oral magnesium supplementation on the lipid profile and blood glucose of patients with type 2 diabetes mellitus. J Assoc Physicians India 2003; 51: 37-42

16. Nielsen FH. Magnesium, inflammation, and obesity in chronic disease. Nutr. Rev. 2010; 68(6):333-40.

17. Song Y, Manson JE, Buring JE, Liu S. Dietary magnesium intake in relation to plasma insulin levels and risk of type 2 diabetes in women. Diabetes care. 2004; 27(1):59-65.

18. Daniels SR. Complications of obesity in children and adolescents. Int $J$ Obes. 2009; 33(S1):S60.

19. Bertinato J, Xiao CW, Ratnayake WN, Fernandez L, Lavergne C, Wood C, Swist E. Lower serum magnesium concentration is associated with diabetes, insulin resistance, and obesity in South Asian and white Canadian women but not men. Food Nutr Res. 2015; 59(1):25974.

20. He K, Liu K, Daviglus ML, Morris SJ, Loria CM, Van Horn L, Jacobs Jr DR, Savage PJ. Magnesium intake and incidence of metabolic syndrome among young adults. Circulation. 2006 Apr 4; 113(13):1675-82.

21. Jose B, Jain V, Vikram NK, Agarwala A, Saini $\mathrm{S}$. Serum magnesium in overweight children. Indian J Pediatrics. 2012; 49(2):109-12.

22. Corica F, Corsonello A, Ientile R, Cucinotta D, Di Benedetto A, Perticone F, Dominguez LJ, Barbagallo M. Serum ionized magnesium levels in relation to metabolic syndrome in type 2 diabetic patients. J Am CollNutr.2006;25(3):210-5.

23. Choi MK, Bae YJ. Association of magnesium intake with high blood pressure in Korean adults: Korea national health and nutrition examination survey 2007-2009. PLoS One. 2015; 10(6):e0130405.

24. Rayssiguier Y, Noe L, Etienne J, Gueux E, Cardot P, Mazur A. Effect of magnesium deficiency on post-heparin lipase activity and tissue lipoprotein lipase in the rat. Lipids. 1991; 26(3):182-6.

25. Guerrero-Romero F, Rodriguez-Moran M. Low serum magnesium levels and metabolic syndrome. ActaDiabetologica. 2002;39(4):209-13

26. Altura BT, Brust M, Bloom S, Barbour RL, Stempak JG, Altura BM. Magnesium dietary intake modulates blood lipid levels and atherogenesis. ProcNatlAcad Sci. 1990; 87(5): $1840-4$

27. Mooradian AD. Dyslipidemia in type 2 diabetes mellitus. Nat Rev Endocrinol. 2009; 5(3):150.

28. Sajjan N, Shamsuddin M. A study of serum magnesium and dyslipidemia in type 2 diabetes mellitus patients. International Journal of Clinical Biochemistry and Research. 2016; 3(1):36-41.

29. Berneis KK, Krauss RM. Metabolic origins and clinical significance of LDL heterogeneity. J Lipid Res. 2002; 43(9):1363-79.

30. Chaudhary DP, Boparai RK, Sharma R, Bansal DD. Studies on the development of an insulin 
resistant rat model by chronic feeding of low magnesium high sucrose diet. Magnes Res 2004; 17: 293-300.

31. Venu L, Kishore YD, Raghunath M. Maternal and perinatal magnesium restriction predisposes rat pups to insulin resistance and glucose intolerance. J Nutr 2005; 135: 1353-58.

\section{The Authors:}

Dr. Sabiha Iqbal,

Assistant Professor,

Department of Physiology,

Central Park Medical College, Lahore.

Prof. Humera Wyne,

Head of Physiology Department,

Central Park Medical College, Lahore.

Prof. Syed Imran Ali Shah,

Head of Biochemistry Department,

Central Park Medical College, Lahore.

\section{Corresponding Author:}

Dr. Sabiha Iqbal,

Assistant Professor,

Department of Physiology,

Central Park Medical College, Lahore.

Email: drsabihafarooq@hotmail.com 